\title{
Changes in the Social Function of Literature in Serbia, 1988-2000
}

\section{MIHAJLO PANTIC}

The break-up of "the second" Yugoslavia (1945-1991) marked the introduction of a new system of political, economic and social relations in the region. ${ }^{1}$ Instead of one, relatively large Eastern-European country, several new states - Slovenia, Croatia and Bosnia and Herzegovina, as well as Macedonia and the FR Yugoslavia - have emerged. Bosnia and Herzegovina consists of the Muslim-Croat Federation and the Republic of Srpska, while the FR Yugoslavia is comprised of Serbia and Montenegro. ${ }^{2}$ The legal status of Kosovo remains unresolved. Changes to the basic type of social relations that were established according to the ideological mantra of communism in the second Yugoslavia, and applied in a more liberal fashion than in other communist states in Eastern Europe, constituted a significant alteration of the earlier dominant cultural model in the newly formed Yugoslav successor states. Instead of the multiculturalism and polyconfessionality that characterized the former multinational union, national/cultural autism prevailed in these former Yugoslav republics. National culture formulated along the lines "I am I" because I do not possess any links to, or similarities with, the "other" gradually hypostatized into the essential measuring tape for the establishment and verification of the relevance of any given work of art. Individual "I"s and collective "we"s are validated by the fact of their own existence, and the superiority of such a presence is then manifested not only through the radicalization of difference regarding the "other," but also through the complete denial of the "other." This is the logic of an ugly paradox: "they" prevent us from being "us"; "I" is not possible if the "other" exists. Half a century of cultural interaction - culture being, above all, the collection of various individual social interactions - turned into its own radical opposite during the early war years of the 1990s. ${ }^{3}$ National cultures (Serbian, 
Croatian and Slovenian) and those cultures that used the period of dissolution of the former SFRY to round up the process of their own historical emancipation (Muslim, Macedonian and to a lesser degree Montenegrin) became possible only within a malignant and overemphasized notion of "difference from neighbors," even though if approached from other analytical vistas (excluding local and chauvinistic ones), such difference always rested in details and nuances. ${ }^{4}$ Instead of these nuances being interconnected, a period of radical antagonism followed. War through art (if we can use the word art without quotation marks) became functionalized and preceded actual armed conflict, and also followed on its bloody heels. We should be reminded here that within the context of the dissolution of the former SFRY, functionalized art represents nothing more than the misuse of external artistic forms. Naturally, we are talking about a particular situation, albeit a very extreme one, which cannot be generalized but which, as a historical specificity, marks the collapse of the ideas of tolerance and coexistence among several nations living in the historically unstable region of the Balkan Peninsula. Here is how it happened and why.

The destruction of "the second" Yugoslavia began long before its final military phase. The dissolution started during the last years of the rule of the Yugoslav communist emperor Josip Broz Tito. After his death in 1980, the conflicts between nationalist-minded party administrations in the Yugoslav republics subsided, only to resurface with renewed vigor at the end of the 1980 s. This tidal wave was particularly apparent after changes in the power structure of the Serbian Communist Party. The process that culminated in war was accelerated by the manipulation of nationalist myths, the instrumentalization of history and the break-up of the socialist system of governing, paired with economic crisis, voluntarism, authoritarianism and a refusal to follow the basic principles of European democracy, as well as attempts by the new political elite to guard amassed material wealth and power. ${ }^{5}$

Another set of reasons for the bloody break-up of the country can be seen in the fact that newly elected national leaders failed to observe the political and diplomatic rules practiced by the international community and to understand the new historical circumstances imposed through the real/symbolic meaning of the fall of the Berlin Wall. Moreover, one should not discount the conflict of interests that was manifestly present in the former union (SFRY) and the unwillingness of the international community to fully understand the intricacies of the Balkan political puzzle and to show resolve in pursuing diplomatic solutions to various problems. All of this means, of course, that one is being wise "after the fact." What is without doubt, however, is the empirical certainty that at the end of the 
twentieth century in the Balkans, history took a sinister turn as so often happens after a war or collective tragedy.

Signs of an imminent war appeared at the end of the 1980s and during the early 1990s, and were apparent on many levels and in different modes. Sport, for example, became an arena for expressing overcharged nationalist sentiments and chauvinistic attitudes. There was even a book that treated this aspect of the Yugoslav crisis; its title, War Started at Maksimir, is indicative of the modes of expressing nationalist frustration in the former Yugoslavia. ${ }^{6}$ Scenes from various sporting events clearly displayed the range of emotional engaging the manipulated masses and are worth remembering. Through these events, the historical spirit of one part of Europe crystallized at the end of the twentieth century. It seems that Europe did not fully understand this segment of its own geopolitical, historical and cultural body of evidence. This might be due to the persistent colonial stereotypes imposed upon the region. A particular stereotype sees the Balkans as somewhat closer (geographically) to the Orient, where the historical, cultural and, finally, democratic processes by which modern people are constituted are not fully formed. The region is perceived as being marked by frequent outbursts of atavistic passions among ethnically close and religiously differing tribes. Every stereotype partially rests upon the truth, but the problem is that every stereotype is constructed through an absolutization of truth or some part of it. It then takes these disjointed segments as principles upon which the entire process functions. But let us return to sport.

The players from two soccer teams, Hajduk from Split and Red Star from Belgrade, cried together with their fans at Poljud stadium in Split on 4 May 1980 when, during the game, the announcer informed them of the death of Josip Broz. A few years later everything had changed. Soccer fans from Split booed during the minute-long silence in memory of one hundred coal miners from the Serbian town of Aleksinac who had perished in an accident. This town would later become a place of carnage after sustained NATO bombing raids in 1999. I remember the stadium in Split in 1990, where Yugoslav athlete Biljana Petrovic (a Serb from Croatia) ran a victory lap during the European Championship in Athletics. She carried two flags: one representing Yugoslavia and another representing the newly establish Croatian state. This event occurred at a time when everyone was conscious that a common state was a thing of the past. The newly elected President of Croatia, Franjo Tudjman, the father of that nation, was in the stands at Split stadium. He regularly attended sporting events and, in the early days of his presidency, was greeted with frantic cheers. By the end of his rule the atmosphere had changed and the crowd often shouted, resorted to harsh criticism of his rule and made loud jokes. But during a soccer match in Zagreb 
between Dinamo (Zagreb) and Red Star (Belgrade) on 13 May 1990 - when the Serbo-Croat war was essentially under way - Tudjman's name was chanted with euphoria. D During his presidency, Serbian leader Slobodan Milosevic never attended sporting events nor was he ever seen in a theater. At the start of his political career, Milosevic organized mass rallies where people in attendance cheered him as the Serbian leader destined to compensate all of their real or mythical national frustrations. Once the initial euphoric phase subsided and until his demise in 5 October 2000, Milosevic lived in seclusion in his own Forbidden City. Whenever he had to venture outside of his compound - to proclaim some kind of victory (economic or military) over the rest of the world - everything was carefully staged and planned. This was done in a manner similar to that of the former North Korean dictator Kim Il Sung. Even today, when the national teams of Croatia and FR Yugoslavia play against each other, victories are valued double, while defeats hurt five times more than before. This is because sports, within the Balkan paradigm, still represent a substitution for war games against an "enemy" that is too closely related.

This is how the political disequilibria manifest themselves through sport. On the other hand, the arts and literature were also battlefields for opposing nationalist forces. Of all professional associations in the former SFRY, the first one to dissolve was the Yugoslav Writers' Union. This organization was established as a carbon copy of the Soviet administrative model. It disintegrated largely because writers were the first to spell out the previously unspoken aspirations of their national party leaders. ${ }^{8}$ The Union was used as a training ground for some kind of democratic surrogate that was to replace (we were told) the socialist system of governing since this system was experiencing a serious crisis. Naturally, this was only rhetoric. Writers were advocates of and litmus tests for the process of the dissolution of the second Yugoslavia. They, nolens volens, formulated and formed antagonistic sets of "national interests" and lived the illusion that their "fifteen minutes" had come, that their voices were being heard and respected. However, all this was occurring in an environment traditionally lacking the skills and culture of "listening." The fact was that writers were then, as before, only marionettes with a certain level of public importance, and were used by the new political oligarchies to legitimize their own positions. It seemed, for a moment, that more liberal times were coming, times when everything could be said and when voicing one's opinion would increase in importance. ${ }^{9}$ In reality this was only a brief interlude that allowed the new/old autocratic and somewhat remodeled system to establish itself as the only master of real power. Words finally lost all their power, if they had ever possessed any. 
By reconstructing the basic elements of a broad historical and cultural context, we have arrived at the crucial distinction marking the change of the social function of literature that occurred after the collapse of Yugoslavia. I will elaborate on this issue within the context of Serbia and Serbian literature. There are various reasons for this narrowing of analytical scope. The primary reason is the fact that I am most familiar with this context and, through my work, belong to it. The second reason rests on my conviction that the aforementioned changes in Serbia represent one of its more radical manifestations in comparison to the cultures and literatures of the other Yugoslav successor states. This radicalism is the product of complexity, extremism and anachronism, as well as the autistic character of the Serbian historical and political situation. Of course, by proceeding in this manner I am not dismissing similarities that are evident within the general trend of transition. I am presupposing their existence. If one is allowed today to think comparatively in Yugoslav terms, such a methodological approach might turn an analysis of potential similarities into a display of empirically proven sameness.

Transition from a socialist cultural model - a euphemism for a watered down version of communism - to a new model applied during Milosevic's rule (that still does not have a name) can be traced and investigated on many levels and in various ways. I intend to rely upon a phenomenological description of details of cultural life, and will focus on occurrences which might indicate central prerogatives of the newly established cultural model. This new model, unlike the earlier one, was not imposed by decree. It simply sprang up like a "wild structure" out of the historical turbulence of the last Balkan war of the twentieth century. After it established itself and it became apparent how this pseudo-cultural model would function, numerous contenders began jockeying for positions of influence.

The semantics of notions such as "literature" and "writer" were the first casualties of this mutation. Previously elitist in character, and representing an art that synthesized and recaptured the general and particular of human experience, as well as an art that deepened the understanding of reality, literature lost its power and social influence in the post-socialist cultural model. It became a very private tale without social significance, a tale that seemed attractive to certain academic circles, to some writers and to an occasional reader whose passion for the written word resembled the passions of other marginalized social groups. There are people belonging to sects that worship Satan and clubs of bullterrier owners, but few people (imagine this) read modern Serbian poetry! The broader social base was indifferent to literature and its ethical strength dissolved into the dark dumbness of lost interests for "imaginative writing." Literature was removed 
from its throne where it had previously sat as a regulator of an unstoppable force that we sometimes call life and sometimes history.

This does not mean that writers stopped writing. On the contrary! Literature is being produced in Serbia under the new circumstances. It is being produced at such a rate that one can say that literary activities and writing in general has become a form of mass activity in Serbia. Such a tremendous growth could seem strange: why write when no one reads or needs the written word? However, if the problem is analyzed more thoroughly it is obvious that this occurrence reflects the absence of any kind of a positive value system in society. Productive social limits have disappeared, and one can state with certainty that in today's Serbia everything is literature. But in a country where everyone is a poet, there are no poets, and the importance of the word as a vehicle of artistic expression is ever more diminishing. In such an environment, you can write anything and this "anything" might be absolutely brilliant. But no one will take any notice of it.

Paradoxically, while literature has lost almost all of its social relevance in Serbia, the reputation of the writing profession has made significant gains. In the cultural and social environment in post-199os Serbia, it has suddenly become important to be a writer, or to be called one. This social signifier is used indiscriminately without even looking into what (if anything) a particular writer has published. Socially relevant literature does not exist any more and even if (and when) it does materialize, no one takes notice. In Serbia today, one can debate the existence of literature but cannot dispute the existence of many writers. There are more of them than ever before. Official writers' associations with dubious functions (neither political, nor ethical and professional) have almost two thousand members. The entire country has some fifty bookstores and approximately two hundred libraries. At the same time, an average print-run reaches between five hundred and one thousand copies for any given book. The obvious question remains: for whom are so many writers actually writing? I cannot come up with an answer that does not include the pseudonym used by Homer's Ulysses when he tried to deceive Cyclops.

In spite of the disheartening realization that in modern-day Serbia the amount of books produced every year is the highest since the codification of the Serbian language while people are reading less than ever before, it is important to be a writer in this country. It is important because of the Serb cultural archetype that a writer act as a social commentator. According to the rules of the mythical/national matrix, the writer is the one who tells us who we are, explains what is happening to us and provides guidance as to what we should do. It is an appealing role, and there is no lack of candidates for this prestigious position. It is a charade and a parade of egoism and self-centeredness, and a tireless competition 
over whose written words will carry more weight and be respected more. With the aforementioned archetype in mind, it is understandable why a battle of pen and paper is taking place in Serbia today. The struggle for literary prestige seems to be an unavoidable consequence of the collapse of the unperfected and incomplete socialist cultural model of yesteryears. The earlier state of affairs was characterized by the existence of a particular hierarchy in which everyone had a designated place to fill and role to perform. Such a model functioned due to an unspoken agreement on the issue of "poetic/aesthetic tolerance." ${ }^{.10}$ In turn, such tolerance provided a space for "dissident" literature and granted relative independence to literary and aesthetic criticism. ${ }^{11}$ The destruction of the old hierarchy in which everyone had a designated place resulted, among other things, in a conflict between several hierarchies established parallel to each other, which did not have anything to do either with aesthetics or with an understanding of the social function of literature but rather with the inevitable struggle for power. This is why, in post-socialist Serbia, we have new party-oriented literatures. As for the process of aesthetic and literary evaluation, the order of the day is self-promotion. Every party has a couple of its own writers. Every party favors and promotes its own perception of literature and its own set of "values," which always correspond to narrow party interests. This practice is so common that it cannot be viewed as a passing trend. Some party leaders - those in power or belonging to real or relative opposition forces - think of themselves as writers with a mission. For a politician or a minister (party leader, journalist, singer of folk songs or lawyer) to say that he is a writer greatly helps to establish his social position. Very often one hears public figures begin to elaborate on any given issue by saying "I, as a writer, think..." In most cases, writing is not perceived as functional literature but is understood as any and all kinds of writing.

This is how, after the collapse of the "second Yugoslavia," literature in Serbia re-established its connection with politics. This time around, such a connection materialized in a more perverse manner than ever before. During the socialist period, literature was given a rather broad maneuvering space as payback for its ideological servitude. Moreover, only certain themes that directly touched upon the mechanism of the communist regime were under political and ideological embargo and constituted a well-marked taboo. Disagreements over literature would arise only when the occasional writer (usually a well-known dissident) attempted to deconstruct this taboo. In the new circumstances it looks like there are no more taboos of any kind (everything can be said, but nothing can be done any more), and language has lost almost all of its corrective powers. It is being used as an unrefined tool for building propaganda banners, which carry different political ideas. 
The second significant change that occurred within the realm of literary and artistic expression is a direct consequence of the total disintegration of all value systems. During the last decade of the twentieth century, Serbian literature suffered from a permanent and intensive diminishing of aesthetic criteria, paired with an occasional advancement of the mantra of the market-value system. If compared with the western cultural model which operates on the principle that a best-seller has to be the best book, the Serbian application of a similar principle and its local variation take the form of a grotesque, since book sales are meager or not even worth mentioning, and because a market for these goods in Serbia does not exist. The cultural infrastructure is indeed intact and we still have publishing houses and libraries, bookstores and institutes, as well as universities and too many literary awards and a relatively broad media landscape. In some areas this existing infrastructure has even been improved upon. For example, instead of the former big and powerful publishing organizations that survived thanks to state sponsorship and were controlled by the state, the publishing industry in the third Yugoslavia is almost entirely privately owned. A distant observer might conclude that everything that is needed for the functioning of a complex literary system is in place in Serbia. There are writers, manuscripts and publishers. The poorly developed literary market in modern-day Serbia has several hundred publishers. What is lacking is a reading public - the reason for the existence of literature and the non plus ultra of every literary activity. Despite the cultural infrastructure's mirage of functionality, the reading public has shrunk to a small circle of professional readers. There is no mass readership and, therefore, there is no elite. During socialist times it was the middle class that made up the reading public. When this class disappeared during the economic downfall of the 1990s, the reading public vanished. The reading of new books (as a way of satisfying a cultural need) is limited to literary critics and writers, even though not all writers read. Anyone else engaged in this activity is motivated by the need for entertainment. Some people go to soccer games (less frequently than before) and others go on picnics (very rarely), while some people read texts built on a rather low-level fabulation. In Serbia, some four million people can read books - they are literate -, and thanks to their school years they possess a vague understanding of what literature is. With this in mind, the fact that best-selling books in Serbia rarely reach a print-run of 10,000 copies speaks more about the state of affairs on the literary front than any socio-cultural analysis.

Literary criticism, the fellow traveler of all recent literary production in Serbia, completely lost its significance. During the past era of ideological oversight, literary criticism defended the artist's freedom of expression and often fenced off political voluntarism and radicalism. No matter to what extent it had to be 
conscious of the ideological context within which literature was created (as adoration, or as negation and indifference, or even as transgression of the current state of affairs), Serbian literary criticism had a crucial role in promoting literary achievements that made Serbian literature an integral part of the European cultural heritage. Its role was apparent in the context of assessing literary values as well as exploring new avenues of critical thinking and presenting new aesthetic forms. Naturally, certain socialist segments of this body of evidence (Serbian literary criticism) remained locked within the confines of an ideological dogma that represented a surrogate/substitute of a denied religion.

Literary criticism in Serbia today has entered a phase of pure solipsism. Decades ago it was argued that literary criticism relied on too many academic terms when describing and analyzing literature, and that such complicated language was not easily understood by a broad readership. Even though this might have been a fair assessment, it is worth reminding ourselves that literary criticism of past decades insisted on the autonomy and multi-layered semantics of a work of art, and that it struggled to prevent the simplification and banalization of literature according to the prescribed mechanism of juxtaposing positive and negative ideological connotations. Today's literary criticism is inward-oriented and caters to a small group of readers, not more than one hundred, because its social function has changed and no one any longer desires to read "academic" and "scholarly written" criticism. Of the several dozen literary magazines and journals that were published monthly in Serbia in the 1980s, only a few remain. Many important journals, such as Delo, Vidici, Savremenik, and Polja, died slow and painful deaths. The few that did survive do not appear on a regular basis and their size has shrunk, while their print-runs are so small that they cannot possibly create what was once known as "mass readership." A certain prestige is still present in journalistic criticism because it emphasizes the informative and advertising function. Due to generally poor living standards criticism also became an activity susceptible to low-level corruption. Critics are essentially servicing publishers by promoting their products. For a meager sum of money a respectable critic will write a review of an ordinary piece of literary trash and hail a mediocre work as the best literary achievements of the decade. Following the changes in literature, literary criticism is also changing. The diminishing influence of criticism is the product of the general dissolution of an earlier literary system, which has been replaced by a chaotic hyper-production that has no self-control and selfreflection.

In conclusion, I will briefly summarize the crucial aspects of an astonishing metamorphosis in the literary arts in post-socialist countries. As I have pointed out earlier, this change took an almost malignant form in Serbia. In spite of the 
fact that literature in Serbia today does not represent a relevant and artistically mediated way of conveying possible truths about the world, every year a few hundred new writers appear on the scene. They struggle at all costs to be accepted as writers and crave this kind of social promotion. They are ready and willing to self-finance the publishing of their manuscripts and to cover all printing costs, editorial expenses and peer reviews, as well as to provide funds for marketing the final product. Once published, these books (novels, collections of poetry) enjoy a few brief moments in the spotlight (the time-frame can be measured in seconds), and are then forgotten and never revisited.

Regardless of this devastating after-shock, it seems that the appeal of being a "writer" never loses its power. Everyone desires to possess and to profit from the right to judge the world. This, in turn, is indirect proof that the entire society functions in a chronic state of anomy where the lack of ethical and aesthetic values is such that it is possible to say that everything is of value - a selfproclaimed everything. Every morning one can read in the daily press information that some contemporary Serbian writer is, at the same time, the most important contemporary Serbian writer. Instead of an interaction of the highest values we are witnessing a leadership race - a model of action that reflects the undemocratic principles of daily politics. The method is always the same, only the names are different. In an environment where everything is of value, there is no value at all. As the most elitist segment of literature, poetry is suffering the unbearable pressure of everyday babbling that no one listens to any more. Every day we have more poets and fewer good poems. Everyone writes and no one reads. Until very recently, approximately one new book of poetry per day was published every day in Serbia, with some of the best Serbian poets (Ivan V. Lalic, for example) having no more that fifty devoted readers of their work. Instead of reading, everyone has taken up a pen and started filling up white pages. Everyone is chipping away at the divine substance of language because everyone wants to be seen as its rightful owner. This is how a poetic substance, which is as rare in a language as gold is in nature, is being constantly smothered by the remnants of wasted language.

I will conclude by saying the following. The position of literature in society is always in some correlation with the quality of that society as shown in example of literature in Serbian society between 1988 and 2000. Speaking in sociological terms, one can state that a worn-out language is the sign of a worn-out society, and the appropriate philosophical metaphor to describe such a state of affairs is that the erosion of a tongue is a clear sign of a heart ailment. 
E N D N O T ES

I The first common South Slav state, the Kingdom of Serbs, Croats and Slovenes (later known as the Kingdom of Yugoslavia) was established on 1 December 1918. The Socialist Federal Republic of Yugoslavia (SFRY) was established in 1945 and is often referred to as the "second Yugoslavia."

2 To say that the SFRY is an "Eastern-European" country represents a relative qualification because this state was never a part of the "Eastern Block," nor was it, in terms of geography, entirely positioned in the east. The SFRY had a system of government that can be characterized as a somewhat relaxed form of partocracy (in comparison to other countries belonging to the "Eastern Block"), and it existed thanks to the Cold War balance of power and interests between two opposing political and ideological spheres of influence. Furthermore, the manner in which its president, Josip Broz Tito, governed the country could be characterized as a "bon vivant" dictatorship. With this in mind, it seems more appropriate to view the former SFRY as some kind of a "bridge" between the communist East and the liberal West. It should also be noted that the SFRY was closer to the communist East because of its lack of civic democracy.

3 This complex of individual social interactions should not be confused with the ideologically defined and proscribed, and administratively favored, idea of the "Yugoslav" cultural integration/unitarization.

4 Specificities of these three cultures (Muslim, Macedonian and partly Montenegrin) had crystallized somewhat later than the period of South Slav romanticism of the Serbs, Croats and Slovenes in the nineteenth century. It is known that the romantic concept of nation presupposes the establishment of a collective, ethnic identity on the basis of tradition, language, self-awareness and religion. In turn, all these elements could be considered within the margins of a general notion of culture: nation $=$ a particular culture. The Macedonian language was codified in 1945, for example, and this codification preceded the formation of the Macedonian state. Muslims were recognized as a nation for the first time after the Yugoslav Census of 1971. Until then, followers of the Islamic faith in the former SFRY were declared either Serbs or Croats or even "nationally undecided." Due to its internal dynamics and complexity the relationship between the Serbian and Montenegrin cultures, which rests upon the category of "specificity within sameness" will not be elaborated on here. The Montenegrin people have their own state, and we know that cultural specificity is one of stately prerogatives.

5 Serbia was the last country in Eastern Europe to call for a multiparty election. Even then, the party in power controlled these elections.

The War Started at Maksimir, Beograd: Medija Centar, 1997. Maksimir is a soccer stadium in Zagreb.

7 Srecko Mihailovic, "Rat je poceo 13. Maja 1990," in Rat je Poceo na Maksimiru, Beograd: Medija Centar, 1997.

The Yugoslav Writers Union ceased functioning in 1989, but its official dissolution was announced in early 1990. After several unsuccessful attempts to organize a meeting of the General Assembly of the Yugoslav Writers Union, its president Slobodan Selenic resigned on 4 January 1990. After his resignation the Union formally dissolved. See: Slobodan Selenic, Iskorak u Stvarnost, Beograd: Prosveta, 1995. 
9 A number of writers received "amnesty" and earlier banned books started appearing in bookstores. The most famous communist dissident, Milovan Djilas, was allowed to publish his books, and the authorities dismantled various party committees that were in charge of monitoring the activities of writers. The collected works of Slobodan Jovanovic, of Dragisa Vasic, and of some other minor writers (such as Stanislav Krakov and Grigorije Bozovic) were published. A new edition of Vunena Vremena, a collection of poems by Gojko Djogo, appeared in bookstores. This poet had been sentenced to two years in prison in 1982 because of his poeticised criticism of Josip Broz. Earlier frequent attacks on "the negative ideological views" in various literary journals stopped. This trend has had a boomerang effect. Since everything can be said, the importance of linguistic engagement has faded away because the language of literature changes the world only as long as it irritates taboos. Once taboos are dismantled, such language loses its bearings. Moreover, the creative efforts of the diaspora were slowly legitimized and became ecstatically less valued but nonetheless an integral part of Serbian literature.

Io During the famous and rather public debate between "realists" and "modernists" in Yugoslav literature during the 1950s, which was monitored by the relevant party structures, an unspoken agreement regarding the validity of artistic ways in pursuing aesthetic values was reached. The imperative agreed upon was the writer's/artist's loyalty to the system, while the avenues through which various aesthetic values were explored were left to the discretion and preferences of individual writers and artists. Thanks to this broad consensus, it was possible to ideologically verify and categorize as elitist art works by such different writers as Desanka Maksimovic, Mihailo Lalic and Branko Copic, on the one hand, and Radomir Konstantinovic, Vasko Popa and Oskar Davico, on the other. This unfair categorization was accomplished in spite of the fact that works by these writers represented perfect examples of the corralling together of authors who exhibited substantially different levels and modes of artistic sensibility and realization.

II For a personal view of this issue, see Dobrica Cosic, Piscevi zapisi I95I-I968, Beograd: Filip Visnjic, 2000. 